\title{
The path of incorruptible culture into Ideological and political education in Colleges and Universities
}

\author{
Yuxue $\mathbf{L v}^{*}$ \\ Qingdao University shandong qingdao 266000, China.
}

Abstract:Traditional culture of clean government has rich connotation,including political ethics, life style, way of life,self-cultivation and other aspects,including benevolent government and loving the people,honest and impartial,impartial law enforcement,lawabiding,thrifty and other ethical norms. The traditional culture of clean government and the idea of Ideological and political education in Colleges and universities are internally consistent and mutually integrated.The combination of the two has profound value implication, which can set a good example of integrity,guide integrity cultivation and optimize personnel training.

Keywords: clean government culture;ideological education; traditional culture

From the structural system of integrity of clean government culture,to integrate the traditional clean government culture into the ideological and political education in Colleges and universities,it can be divided into two different parts:one is the external part of clean government organization,clean government environment,clean government system, and the other is the internal abstract part of clean government thought,clean government consciousness,clean government psychology. We can promote the integration of traditional anti-corruption culture into the ideological and political education in Colleges and universities from the aspects of curriculum integration, organization integration,management integration, and culture integration.

\section{Classroom integration:promoting the classroom teaching effect of traditional clean government culture}

On the one hand,we should give full play to the dual subjectivity of teachers and students. The classroom is not a teacher's speech,but a place of knowledge dissemination formed by the interaction between teachers and students. The traditional education mode overemphasizes the subjectivity of teachers and emphasizes the cramming education. Teachers have the absolute right to speak, and students should accept the teacher's instruction unconditionally and passively.The subjective status of both teachers and students is covered,which damages the effect of Ideological and political education in Colleges and universities. Therefore,we need to give full play to the subjective role of teachers, through teachers'accurate grasp and deep understanding of the traditional clean government culture,actively guide students to learn the knowledge of clean government,conduct in-depth thinking and

doi: $10.18282 / 1-$ e.v9i4.1699

This is an open-access article distributed under the terms of the Creative Commons Attribution Non-Commercial License (http://creativecommons.org/licenses/by-nc/4.0/), which permits unrestricted non-commercial use, distribution, and reproduction in any medium, provided the original work is properly cited.

\section{CONCLUSION}

Overall,according to the theories of Vickroy's, the trauma narrative manifests itself through aspects of fragmentation,the capacity to produce metaphors and motifs, and trauma incarnate. The fragmentation to confine herself in a disguise,the metaphors and motifs of trauma, and the collide of collective and personal memories have attributed to the analysis of trauma narratives in Hiroshima Mon Amour.The characters of"she"and"he"would also be interpreted as"you"and"me"to the spectators,revealing their trauma experience concerning the historical events or personal memories.In retrospect,past experience adds weight to the duration of time and arouse the question of forgetfulness. Though the analysis of narrative discourse and sound,the characters in the film are immersed in the inescapable prison of trauma.

\section{Reference}

[1]Gunning,T.(1999).“ Narrative Discourse and the Narrator System.” Leo Braudy and Marshall Cohen,eds.Film Theory and Criticism: Introductory Readings.5th ed.New York:Oxford University Press.[2]Vickroy,L.(2002).Trauma and Survival in Contemporary Fiction.United States:University of Virginia.

[3]Segal,H.(1981).“ Notes on Symbol Formation.” The Work of Hanna Segal:A Kleinian Approach to Clinical Practice.New York:Aronson. 49-65.

[4]Keating,P.(2010).Hollywood Lighting from the Silent Era to Film Noir.United States:Columbia University Press.

[5]Friedlander,S.(1992).“ Trauma,Transference,and“ Working Through’ in Writing the History of the Shoah” History and Memory.(4):3959.

[6]Chion,M.(1990).Audio-vision:Sound on Screen.New York:Columbia University Press.

[7]Laub,D,and Nanette C.A.(1993).“ Knowing and Not Knowing Massive Psychic Trauma:Forms of Traumatic Memory.” International Journal of Psychoanalysis (74.3):287-302. 
immediate action, and improve the effect of traditional clean government culture education.In addition, it is necessary to establish students'subjectivity,enhance their self-education,improve their subjective initiative,actively learn traditional knowledge of clean government,and consciously improve their awareness of clean government.Giving full play to the dual subjectivity of teachers and students is conducive to enhancing the communication between them. Teachers guide students,students feed back teachers,and jointly build a harmonious and flexible clean classroom.

On the other hand, it highlights the diversity of theme class.After all,the traditional culture of clean government has its own independent system and history.To fully carry forward the traditional culture of clean government,in addition to integrating into the ideological and political class and professional class,we can also set up the theme class of clean government to teach and discuss the knowledge of clean government culture.For example,Qingdao University offers a general education elective course"College Students'integrity education"for undergraduates.This course is taught by professional teachers through the standardized classroom,so as to realize the wide coverage of College Students'integrity education.However,the survey found that most colleges and universities did not set up a special anti-corruption education class, but mixed with some anti-corruption content in the Marxist theory class, which accounted for a small proportion and had poor effect.Therefore, it is necessary to mobilize colleges and universities to actively set up anti-corruption theme class,construct a perfect curriculum syllabus, and construct a comprehensive teaching content from many aspects.

\section{Organizational integration:strengthening the influence of traditional clean government culture on party and League organizations in Colleges and Universities}

In recent years, the number of college student party members has been increasing.According to the latest statistics in 2018, there are 43.286 million Party members with college degree or above,accounting for $48.3 \%$.College students are the main participants in the construction and activities of the party and League in Colleges and universities, and the party and League organization is an important platform to carry out ideological and political education,and a position to exercise and cultivate the comprehensive quality of students,especially student cadres.Integrating the traditional culture of clean government into the party and league construction can enhance the ability and level of College Students'self-education and self-management ${ }^{[1]}$.

The school party and League organizations should play an exemplary and leading role,actively organize party members and League members to receive anti-corruption culture education,distribute anti-corruption materials in the training classes for Party building backbones,new party members, probationary party members and party activists,and carry out anti-corruption special party courses,so as to correct College Students'motivation to join the party and enhance Party members'Anti-corruption quality.

\section{Enhancing the leading role of clean government in the daily management of colleges and Universities}

The education and management of clean government in Colleges and universities is an important part of the school management system, and also an important part of the cultural education of clean government.Colleges and universities should pay attention to it and provide more support and convenience for the promotion of the education of clean government.

On the one hand,it is necessary to build a constraint mechanism.In the process of building a clean government culture,the restraint mechanism,as a"hard"element,solidifies the clean government culture in a normative and compulsory mode as a common agreement and code of conduct that everyone must abide by,and implements it to the letter,so as to"strongly"promote the integration of the clean government culture into the group values.In addition, the restraint mechanism can also play the role of prevention. Facts have proved that only relying on"soft"means of education can not really restrict people's behavior.Faced with all kinds of temptations and the situation of"low cost of doing evil",it is easy for the actor to break through the inner moral standards and values of clean government,so as to make inappropriate behavior.However,to play the role of rigid restraint mechanism does not mean that we should really take a tough attitude to meet the tough,and we should take into account both the immediate effect and the long-term effect.At the beginning of the implementation of rigid restraint mechanism,flexible policies can be applied to split the rules and regulations in the restraint mechanism into the most basic units and implement them in the daily life of teachers and students,so that they can really identify with the mechanism, develop good habits of clean government,improve individual behavior and shape honest character.

On the other hand,teachers'ethics construction."If he is upright,he will act without being ordered.If he is not upright,he will not follow the orders."the so-called"upward but downward effect"means that he is not upright.How can he be upright?Teachers are not only the main witnesses of the construction of campus clean government culture,but also the backbone participants and guides of campus clean government culture ${ }^{[2]}$. They play the role of answering students'questions and guiding the direction,and undertake the important task of cultivating college students into high-quality talents with sound personality,noble morality and free from low taste.The duty of university teachers is not only to impart knowledge,but also to cultivate morality. Therefore,it is an important premise to strengthen the training and sense of responsibility of the teachers. The most urgent task is to carry out political and ideological education and anti-corruption education among teachers,and bring the education of clean government into the category of teacher's ethics education.It is also necessary to be hard to forge iron.In addition, it is necessary to build a mechanism of supervision and reward for teachers,restrict and encourage teachers'words and deeds, build a system and framework of teachers'ethics and style,and work hard and soft to ensure the formation of a clean and honest style of teachers.

\section{Reference}

[1]Zhang Xiandong(2016).Analysis on the incorruptible education mode of College Students under the new situation[J].Legal system Expo,(03),(67)

[2]Dong Chenyan, Yu Hongguo(2016).Research on Problems and innovation promotion countermeasures of College Students' integrity education[J].Vocational education communication,(14). 